forty years, addicted to the use of morphine from the age of sixtecn, in whom pale, hluish spots, similar to those produced by tattooing with Indian-ink, symmetrically diatrihuted over the thigh, bad followed injections of morphinc. Tbese spots were rounded or elongated, 2 to 3 millimetres in diameter, with a slight cicatricial depression. Bistological exanination of the spots showed the presencs of black grnins nf unequal size, insolnhlc in alcohol, potash, and concentrated acids, and not giving the reaction for iron, and otbers transparent nad refractive, with shnrp corners. The first seemed to he particles of carhon, the others, pnrticles of silica.

Eczema Prodnced by Formalin.-Fisnen (Brifish Journal of Derona(ology, August, 1901), in a clinical note records his experience of the irritating effects of formalin upon the akin. He was accustomed to use this antiseptic in the preparation of museum specimens, more especinlly in the winter; and during sevcral successive winters he suffered from an eczcma of the fingers, which was at first attribnted to the frequent wetting of the hands, hut was suhsequently found to he dne to the use of formalin. Others who worked with him were similarly affected. Snsccptibility to the irritant effects of formalin seems to he more or less gradually ncquired. For a tims the bands may he daily dipped into formulin solutions varying in strength from 1 to 5 per cent. without ill effects; then itching and vesicles begin to nppcar, which result in tcoublesome eczema if the use of the formalin is not immediatcly given up. The susceptihility of the skin is much increased nfter such an attack, mere handling of specimens preserved in formalin being sufficlent to cause a retura of tbe eczemn.

The Histopathology of Two Cases of Cntaneons Truberculides, in One of which Tnbercle Bacilli were Found.-MAcLEOD nnd Orusny (Brilish Journal of Dermatology, Octoher, 1901) exsmined the lesinns from two cases of cutaneous tuberculides. These lesions were acne-like, hluish-red nodules, situated in ths one case on tbe extensor aspect of hoth legs helow the knees, in the other upon the forearms, hips, thighs, and legs. The histological appearances found were as follows: In hoth cases the initial changes appeared to he in the hypoderm, and consisted of proliferative changes in and cellular hyperplasia around the veins in that region. In hoth the cellular infiltration rapidly encroached upon and replaced the fat tissue, forming cellulur aress more or less encapsulated hy the rcmains of the interlohar septa. It is this early cellular infiltration which is to a large extent confined to the hypoderm, which gives rise to the deep-seated nodules which are scrrcely visihle clinically, hut are usually appreciahle to the touch. In hoth the cellular infiltratinn extended upward along the capillaries, forming foci in the neighhorhood of the sweat-coils, hair-follicles, and sehaceous glands, and finally reached the papillary layer. In hoth the character of the cellular hyperplagia was aimilar. In the hypoderm it was more markedly tuherculous in appearance in the aecond than in the first case, hut in both the foci in the corium presented equally the characteristic tuherculous architecture. Tuhercle hacilli were found in the giant cell in the latter crae. A fibrous stroma supporting the cellnlar hyperplasia was either entirely ahsent or was represented by cedematons, degenerated collagen and 
elastin. In hoth cases the cellular hyperplasia dereloped at the expense of the tissue in the neighborhood and finally hecame necrotic. The papillary and the suhpapillary ressels were congested as soon as the infiltration began to encroach upon the corium, accounting for the congested appearance which the nodnles presented clinically. The epidermis was only secondarily affected.

The two cases clinically and histologically had certain mnrked features in common. In the second ense there wng a dactylitis and $\mathrm{n}$ tuberculous family history; tubercle bacilli vere found in the lesions of this case. Although no hacilli were found in the lesions from the first case the similarity of the histological a ppearances left little doubt in the minds of the nuthors that it was also tuberculous.

[This report is of extreme interest, furnishing indubitable evidence of the tuherculous nature of these lesions.-M. B. H.]

\title{
HYGIENE AND PUBLIC HEALTH.
}

\author{
TNDEE THE CHARGE OF \\ CHARLES HARTINGTON, MI.D., \\ LESISTANT PEOTESOR OY IYOLESE, IIAEVATD YEDICAL BCHOOL, \\ $\triangle N D$ \\ EDWARD F. WILLOUGHBY, MI.D., \\ or LoNDOS.
}

Influence of Boric Acid and Borax upon the General Metabolism of Children-Boric acid nnd bornx nre much used as food preservatives, nnd the question of their influence upon the general uutrition of the consumer is oae of great interest. The literature on the subject is very voluminous, but the conclusions drawn by the inrestigators are most conflicting. In order to obtain reliable data upon which to hase conclusions, Drs. F. W. TUNNIclifFe nnd Otro Rosenhersi (Joumal of Hygiene, April, 1901, p. 168) condueted a series of comparative metabolie observations on the human suhject, extending over n considernble period. The ohservations wero made upon three children, who were kept under constant supervision. Their iagesta were accurately weighed and their excreta were collected daily without loss. Both ingesta and excreta were carefully analyzed hy the most approved methods. The resnlts of the very unmerous analyses are given in detzil. The general conclusions arrived at $\mathrm{may}$ be summarized as follows : Boric acid in sciall doses up to 1 gramme per diem; continued for some time, exerts no influence upon proteid or phosphorus metaholism, has no effect upon the assimilation of fat, and exerta no inhihitory effect upon intestinal putrefaction. Body-weight increnses. The quantity of dry feces is not affected, but their nitrogen and phosphorus percen tage is slightly decrensed. Borax in continued doses of 1.5 gramme has no infinence upon proteid or phosphorus metabolism, may or may not improre fat assimilation, does not interfere with increase in weight, hag no effect upon the weight of dry feces 
and their uitrogen and phosphorus percentage, nod tends to inerease intestinal putrefnction. Both horic acid und horax nre quickly eliminnted, hence cumulative action is improhahle. Neither anbstance will affect the genernl health nad well-heing.

Puriflcation of Water by Sodinm Bisulphate.-Tnhloids of sodium hisulphate have recently heen recommended hy Drs. Pnrkes nnd Rideal for the treatment of water liy nrmies in the field. Three tahloids nre dissolved in cach pint of water, and fifteen minutes' contact nllowed before drinking. Thcy state thnt B. typhosus is killed hy only fire minutes' contnet with the agent in the proportion of $\mathbf{1 5 . 5}$ grains to the pint, hut recommend fifteen minutes to insure sterility. The process has heen tested hy Dr. A. W (Public Meallh, July, 1901, p. 700), who fonnd that a contact of fiftcen minutes causes a striking reduction in the number of typhoid hieterin in $\mathrm{m}$ infected wnter, but does not produce sterility. In n majority of cases the hacillus is completely destroyed by n contact of thirty minutes. B. enteritidis is as resistant as B. typhosus, nnd B. coli communis wtill more so. B. eholera is destroyed in ten minutes. It has heen claimed that the tahloids impart an agreeable neid taste and mnterially nid in quenehing thirst, lut Warner asserts that to some the taste is unpleasant nnd rould prolsably soon hecome jrksome. A soldier drinking five pints of wnter in a day nould smallow over seventy-five grmins of the salt, an amount whieh, Wnrner suggests, would have the effect of inereasing thirst rather than of quenehing it.

A New Test for Formaldehyde in Milk. - In the process of estimating nitrogen $\mathrm{hy}$ the $\mathrm{K}$ jeldahl-Gunning method in $n$ number of samples of milk whieh hnd heen preserved with formalin, A. G. LoEBent (Joumal of the American Chemical Socicly, September, 1901, p. 682) notieed n peeuliar violet coloration of the potassium sulphato erystals nnd of the sulphuric ncid surrounding them. This was especially mirked when the milk was ndded to the potassium sulphate. nnd the acid carefully poured down the side of the digestion flagk so that the liquids did not mix, and did not occur with milk which contained none of the preservative. He reeommends the following test: Firc grammes of cosrsely powdered potassium snlphate nre placed in a 100 e.e. flask, 5 c.e. of the suspected milk nre distrihuted over it hy means of a pipette, and 10 e.c. of sulphurie neid (specific grnvity 1.84) earefully pourcd down the side of the flask. The whole is now allowed to stand quietly until the color develops. If formaldehyde is present, the violet coloration occurs in $\mathrm{n}$ fer minutes; if none is prescnt, the liquid will at once assumc a brown color, rnpidly changing to hluek. The test is said to revcal the presence of one part of formaldehyde in 250,000 of milk.

Notice to Contributors. - All communicstions inlended for insertion in the Original Department of this Journal are received only with the distinet undersianding that they are contributed exelusitely to this Journal.

Contribotions from nbroad written in a foreign lnnguage, if on eraminntion they are found desirable for this Jonrunl, rill he translated nt its expense.

Liheral compensation is made for articles used. A limited number of reprints in pamphlet form will, if desired, be farnished to nuthors in lien of compensation, provided the reguest for them be terillen on the manuscript.

All communications should be addressed to

Dr. Frascis R. Paerann, 1831 Ghestnnt Street, Philadelphia, U.S. A. 
T $\mathbf{E}$

\title{
AMERICAN JOURNAL
}

\section{OF THE MEDICAL SCIENCES.}

\author{
APRIL, 1902 .
}

\section{CASES ILLUSTRATIVE OF THE LOCALIZATION OF THE BIENTAL FACULTIES IN THE LEFT PRE- FRONTAL LOBE. \\ By Charleg Phelpe, Mi.D.,

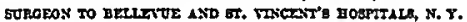

Atresrpss to localize the mind in the human hody began almost as early as the recognition of its existence. Theories were successively formulated during many centuries which were wholly speculative and often without a vestige of reason, hut which followed a logical eequence and led to rational, though usually mistaken, conclusions. The successive steps in this progressive development of an idea were the separation of the moral from the intellectual faculties; their localization in different organs; their recomposition in the brain; the restriction of the mind to a definite seat in some one of the various encephalic regions; and, finally, the assignment of individual mental faculties to separable cerehral areas. The several phases of localization enumerated were not chronologically distinct. During the whole period of from twentythree to twenty-four centnries as new theories were developed older ones persisted. There could he no settled beliefs because there were no sufficient foundations of fact, and while much of the anatomy of the brain became known, little of its physiology or pathology was discovered.

In the first decade of the nineteenth century a more rational study of cerehral physiology than had heen made hefore was undertaken hy Gall, who was also the first to conceive the iden of a methodical plan of cerehral Iocalization. His Iater work, in collahoration with Spurzheim, which included not only cerehral physiology and anatomy together with cranioscopy, hut also psychology, profoundly impressed the minds of his contemporaries and immediate successors. His theory of Iocalization, founded upon a comparison of known or assumed individual voL. 123, xO. 4-APEII, 1902 